\title{
PEREMPUAN DALAM WAYANG SUNDA: ANALISIS WACANA KRITIS TERHADAP LAKON DRAUPADI DAN ARIMBI
}

\author{
Farieda Ilhami Zulaikha ${ }^{1 *}$, Sundari Purwaningsih ${ }^{1}$ \\ ${ }^{1}$ Universitas Perjuangan Tasikmalaya, Indonesia \\ *e-mail: fariedailhami@gmail.com
}

\begin{abstract}
Abstrak
Penelitian ini bertujuan untuk mengkaji hubungan sebuah karya dan masyarakat Sunda, dan Draupadi dan Arimbi sebagai tokoh perempuan yang menggambarkan relasi kuasa dalam masyarakat Sunda. Penelitian ini menggunakan kerangka analisis Feminist Critical Discourse Analysis (FCDA) untuk menggambarkan narasi kuasa yang terjadi pada lakon Arimbi dan Draupadi. Penjelasan terkait pengaruh wayang terhadap identitas perempuan dalam masyarakat tradisional Sunda diperoleh dari observasi yang dilaksanakan di Dusun Cengkir Manis, Desa Cinyasag, Kab. Ciamis, Jawa Barat. Hasil penelitian ini menunjukkan bahwa narasi kuasa pria pada lakon Draupadi dan Arimbi yang akhirnya mereproduksi identitas perempuan dan laki-laki dalam masyarakat patriarki. Praktek itu terlihat melalui fenomena komodifikasi dan objektifikasi dalam masyarakat tradisional Sunda. Perempuan menjadi entitas yang ditandai atau dikenal dengan sebutan marked society dalam dunia heteronormatif.
\end{abstract}

Kata kunci: Wayang Sunda; Analisis Wacana; Draupadi; Arimbi; Relasi Kuasa

\begin{abstract}
This research investigated the relationship between literary work and Sundanese. And also, Draupadi and Arimbi as symbols of power relations in Sundanese culture. Encompassing Feminist Critical Discourse Analysis (FCDA), this framework illustrated power relations between men and women through Draupadi and Arimbi. An observation that was administered in Dusun Cengkir Manis, Desa Cinyasag, Kab. Ciamis, West Java, demonstrated how puppetry reproduced a woman's identity in traditional Sundanese society. The findings illuminate male domination over women that reproduces woman and man identity in the patriarchal order. It can be seen through commodification and objectification in traditional Sundanese society. Women become a marked society in heteronormative order.
\end{abstract}

Keywords: Puppetry; Discourse Analysis; Draupadi; Arimbi; Power Relation

This is an open access article under the CC BY-SA license.

Copyright @ 2021 by Author. Published by Universitas Pendidikan Ganesha.

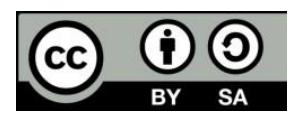




\section{PENDAHULUAN}

Dalam perjalanannya, wayang menjadi salah satu media untuk menyisipkan pesan agama dan nilainilai moral yang menggambarkan sebuah masyarakat (Suryana, 2002, hlm. 20). Konsep alam semesta yang tergambar dalam sebuah kebudayaan dikategorikan oleh Geertz (1973) sebagai world view atau pandangan hidup. World view ini didasari oleh aspek kognitif dan eksistensial dalam budaya. Geertz juga menemukan bahwa selain world view, wayang pun sarat aspek moral dan estetik yang kerap disebut dengan ethos. Hal ini didukung oleh penelitian - penelitian lainnya yang juga mendukung bahwa wayang adalah manifestasi kebudayaan yang kaya akan nilai fiosofis (Suryana, 2002; Tofani, 2013; Hasuna, K. 2015; Sabunga, et al., 2016; Sukmawan \& Supendi, 2016; Miranti \& Amzy, 2018; \& Schauf, et al., 2018). Pesan yang disampaikan kemudian dibungkus dalam pesan konotatif dan denotatif. Banyaknya nilai yang terkandung dalam pertunjukan wayang ini membuat Sabunga et al., (2016) menyimpulkan bahwa pertunjukan wayang merupakan media pembentuk karakter dan kepribadian yang kaya akan nilai nilai kebaikan Tuhan yang berorientasi pada pembinaan perilaku. Sehingga terlihat jelas bahwa wayang memiliki peran penting dalam membentuk perspektif sebuah masyarakat. Wayang memanfaatkan media bahasa yang dikemas ke dalam sebuah pementasan yang menarik bagi penonton yang secara tidak sadar akhirnya menginternaslisasi nilai-nilai yang disampaikan melalui lakon-lakon wayang. Pesan moral kerap disampaikan secara verbal baik melalui dialog-dialog yang terjadi antara tokoh wayang maupun monolog. Dialog ini disebut dengan antawacana.

Dalam dialog tersebut muncul identitas dari setiap lakon yang diterima oleh masyarakat dimana representasi gender menjadi sangat menarik untuk diteliti dari para lakon wayang karena setiap lakon merepresentasikan identitas ideal dalam sebuah masyarakat. Identitas ideal ini merupakan integrasi dari nilai nilai moral dan pesan agama yang ingin disampaikan. Kajian menjadi semakin menarik ketika terjadi perdebatan terkait repsentasi perempuan pada lakon wayang dalam salah satu cerita wayang terkenal, Mahabharata. Hasuna (2015) menyimbolkan Dewi Kunti sebagai lambang kesucian dan mampu menahan hawa nafsu. Sehingga Dewi Kunti menjadi parameter idealnya seorang perempuan dalam masyarakat Banjar. Selain tokoh Dewi Kunti, Srikandi diagung-agungkan sebagai lakon wanita pemberani dalam cerita wayang sehingga dipercaya sebagai tokoh perempuan yang turut memperjuangkan emansipasi wanita. Setyowati (2013) mempercayai bahwa wayang tidak hanya mengajarkan bagaimana menjadi wanita santun dan berperangai baik, tetapi juga bagaimana menjadi perempuan yang tangguh. Hal ini dapat terlihat dari lakon Srikandi. Srikandi digambarkan sebagai perempuan yang handal dalam 
menyusun strategi perang. la mampu mengalahkan musuh dalam perang melawan Kurawa. Munculnya tokoh srikandi dalam wayang dianggap sudah mampu mengusung relasi kuasa yang seimbang antara perempuan dan lakilaki. Sharma (2013) juga turut mendukung dengan menyatakan bahwa perempuan telah berhasil menciptakan ruang geraknya sendiri yang membuat pria tak berkutik dan menuruti keinginan wanita. $\mathrm{Hal}$ ini terlihat pada tokoh-tokoh penting dalam wayang seperti Dewi Kunti, Srikandi, Drupadi, dan Arimbi. Dewi Kunti sendiri dianggap sebagai simbol perempuan yang cerdas dan bijaksana yang paham akan permasalahan bangsa dan negara sehingga tidak kalah dengan pentingnya peran para pria dalam wayang (Sudjarwono, et.al, 2010).

Namun, Kaur (2018) membantah anggapan tersebut. la menyatakan bahwa dengan lakon Srikandi dalam cerita wayang tidak lantas menghapus relasi kuasa yang terjadi. Lakon wayang yang ia gambarkan sebagai korban dari opresi gender adalah Draupadi. Jika dilihat sekilas, Draupadi muncul sebagai wanita pemberani, pintar dan dicintai oleh suaminya. Tetapi jika dilihat kembali, hal yang terjadi tidaklah demikian. Romantisasi diciptakan sebagai pemanis relasi kuasa. Draupadi lebih sering dianggap sebagai barang kepemilikan suami. Hal ini ditandai dengan sebuah adegan dimana suami tertua Draupadi kalah dalam judi. Draupadi disajikan sebagai hadiah kepada Kurawa yang memenangkan judi tersebut. Dari cerita ini, penggambaran tentang kuasa pria terhadap tubuh wanita menjadi hal yang menarik untuk dikaji lebih dalam. Hal inilah yang akhirnya membuat peneliti tertarik untuk mengkaji seberapa penting pengaruh wayang sebagai salah satu karya sastra dalam masyarakat Sunda dan bagaimana tokoh wayang mampu merepresentasikan perempuan dalam masyarakat Sunda. Penelitian ini merupakan rangkaian dari studi budaya lokal Sunda dan hubungannya dengan identitas sosial khususnya gender. Penelitian sebelumya menemukan bahwa budaya lokal masih sangat berpengaruh dalam kehidupan bermasyarakat suku Sunda (Zulaikha \& Purwaningsih, 2019). Selain itu, peneliti juga menemukan bahwa peribahasa Sunda sarat akan relasi kuasa. Seperti halnya peribahasa yang merupakan salah satu produk kearifan lokal dari masyarakat Sunda, wayang pun diyakini mampu untuk menunjukkan bagaimana identitas gender terbentuk dalam wayang yang selanjutnya mempunyai peranan untuk mengkonstruksi nilai dan konsep ideal dalam masyarakat.

Penelitian ini berfokus pada analisis tekstual yang muncul dari dialog yang terjadi antara para lakon dan observasi ke desa tradisional yang masih sering mementaskan wayang dengan pendekatan wacana kritis feminis. Analisis wacana kritis feminis mengutamakan hubungan antara praktek sosial khususnya gender dan wacana sehingga kerangka analisis ini diyakini dapat menguak relasi kuasa yang terjadi dalam cerita wayang Sunda melalui representasi perempuan 
dalam lakon wayang Sunda. Desa tradisional yang menjadi daerah observasi adalah Dusun Cengkir Manis, Desa Cinyasag, Kab, Ciamis, Jawa Barat. Peneliti kemudian menitikberatkan pada dua lakon perempuan penting dalam wayang Mahabharata yakni Draupadi dan Arimbi. Selain itu, pemilihan dua lakon ini didasari oleh identitas yang kompleks yang disematkan pada Draupadi dan Arimbi. Arimbi dianggap perempuan yang berani dan setia terhadap pera suami, tetapi juga merupakan simbol objektifikasi perempuan seperti yang ditemukan pada penelitian sebelumnya. Sedangkan Arimbi merupakan perempuan perkasa yang sangat mencintai suaminya, namun kerap merubah wujudnya dihadapan suami dari seorang raksasa ke sosok manusia. Kedua alasan inilah yang melandasi pemikiran awal peneliti terakit adanya relasi kuasa dalam cerita wayang Sunda. Hasil dari penelitian wayang Sunda ini diharapkan dapat menjadi kajian bersama sdan mendukung Pengarusutamaan Gender (PUG) dalam semua bidang masyarakat. Kebudayaan lokal menjadi salah satu hal yang penting untuk mendapatkan perhatian sebagai upaya menanamkan nilai-nilai PUG dalam masyarakat.

\section{METODE}

Penelitian ini menggunakan metode deskriptif kualitatif. Metode deskriptif adalah sebuah metode yang menganalisis data berdasarkan realitas faktual. Metode pengumpulan data yang dilakukan oleh penulis adalah metode simak dan observasi. Metode simak ini peneliti lakukan dengan cara observasi tidak langsung. Peneliti menonton penampilan wayang Sunda dengan karakter utama Arimbi dan Draupadi. Ketiga karakter utama ini dipilih karena dipercaya sebagai karakter perempuan yang kuat dalam cerita Mahabaratha. Kemudian untuk melihat praktek sosial dalam masyarakat yang diturunkan dari cerita wayang ini, peneliti melakukan observasi di Dusun Cengkir Manis, Desa Cinyasag, Kab. Ciamis, Jawa Barat. Pemilihan tempat penelitian ini didasari oleh beberapa alasan yakni: 1) dusun tersebut masih dapat dikategorikan sebagai masyarakat taradisional karena memenuhi persyaratan seperti masyarakat bersifat homogen, bersifat agamis, mobilitas rendah dan menerapkan aturan yang kuat dari nilai yang mereka percayai seperti halnya nilai yang diproduksi dan direproduksi dari cerita wayang dan 2) wayang masih sering dipentaskan dan memegang peranan penting dalam kehidupan bermasyarakat seperti dalam acara ruwatan.

Teknik yang digunakan dalam mengalisis data ini adalah teknik analisis wacana kritis dengan analisis wacana kritis feminis Lazar (2005) yang terbagi menjadi tiga tahap: 1) description, 2) interpretation, dan 3) explanation. Tahap interpretasi dimulai dengan analisis kosakata, dan percakapan yang terjadi dalam cerita. Peneliti juga menganalisis konteks bagaimana konteks cerita memproduksi 
cerita secara keseluruhan. Selanjutnya peneliti melanjutkan ke tahap description dan explanation untuk dapat menjelaskan lebih dalam terkait narasi gender yang mencakup 1) karya sastra dan hubungannya dengan masyarakat Sunda; dan 2) Penggambaran Draupadi dan Arimbi dan cerminannya dalam masyarakat Sunda posisi perempuan dan laki-laki dalam masyarakat Sunda sebagai cerminan dari cerita wayang yang dimainkan melalui penggambaran Draupadi dan Arimbi dalam masyarakat tradisional Sunda di Dusun Cengkir Manis, Desa Cinyasag, Kab. Ciamis, Jawa Barat.

\section{HASIL DAN PEMBAHASAN \\ Karya Sastra dan Hubungannya dengan Masyarakat Sunda}

Karya sastra selalu menjadi cerminan dari sebuah masyarakat karena mampu menggambarkan kondisi yang terjadi dalam pada kelompok tersebut seperti halnya cerita wayang. Cerita yang awalnya berasal dari India ini diadaptasi ke dalam budaya Sunda yang akhirnya menciptakan cerita yang sarat akan konsep ideal yand diinginkan oleh masyarakat tersebut. Cerita wayang mengandung nilai-nilai filosofis kehidupan seperti nilai agama dan norma sosial yang ada dalam masyarakat. Dalam setiap pentas wayang, isu-isu hangat dan penting bagi masyarakat kerapkali dibahas oleh para lakon. Wayang mampu menjadi media penyampai informasi yang ada dalam karya sastra kepada masyarakat (Koentrajaningrat, 2002).
Salah satu kisah epos yang terkenal dalam pewayangan Sunda adalah Mahabharata. Mahabharata menawarkan cerita yang sarat dengan nilai filosofis dan spiritual. Cerita ini pun menawarkan konsep ideal dalam masyarakat termasuklah di dalamnya konstruksi identitas gender. Mahabharata menceritakan tokoh utamanya yakni Pandawa dan hubungannya dengan para Kurawa. Plot utama dari cerita Mahabharata adalah tentang perebutan kekuasaan dalam kerajaan Hastinapura. Konflik dimunculkan melalui tokoh Pandawa dan Kurawa yang merupakan saudara sesepupuan dari dua saudara kandung yakni Pandu dan Destarata. Perebutan kekuasaan mulai muncul ketika Duryudana menolak memberikan tahta kepada Yudistira. Kelima Pandawa akhirnya pindah ke hutan untuk menghindari perang saudara. Dari sinilah dimulai perjalanan kelima pandawa hingga bertemu dengan para istri yang cantik dan patuh seperti Draupadi dan Arimbi. Untuk menambahkan unsur lokal dalam cerita wayang Sunda, Cepot ditampilkan sebagai tokoh yang kerap melucu, namun penuh akan kebijaksanaan.

Begitu lekatnya wayang dalam masyarakat Sunda, lakon wayang dianggap sebagai simbol dalam masyarakat khususnya simbol bagi perempuan dan laki-laki. Cepot menjadi simbol pria yang berwajah tidak tampan, mempunyai kulit wajah yang merah, dan gigi yang menonjol keluar. Selain Cepot, lakon wayang lainnya yang kerapkali disebutkan dalam peribahasa adalah Sinta dan Rama 
dalam epos Ramayana. Sinta menjadi simbol istri yang ideal bagi para suami. Sinta menyimbolkan kepatuhan, keindahan, dan kesetiaan. Sedangkan Rama menyimbolkan suami yang gagah dan tampan. Selain Rama, Arjuna dari keluarga Pandawa pun sering dijadikan simbol pria gagah, pintar, dan tampan yang mampu menarik hati para wanita.

Dalam epos Mahabharata terdapat beberapa tokoh perempuan yang terkenal dalam keluarga Pandawa yakni Draupadi dan Arimbi. Kedua wanita ini dikenal sebagai wanita yang tangguh dan kuat. Draupadi adalah istri dari Pandawa yang pintar, cantik dan tangguh. Arimbi adalah istri Bhima yang merupakan bangsa raksasa. Kedua lakon ini menyimbolkan nilai nilai feminis yang mampu memberikan sosok lain diluar kelembutan yang selalu melabeli perempuan (Setyowati, 2013). Namun, jika dilihat lebih dalam, lakon Draupadi dan Arimbi sarat akan represi gender.

Ketimpangan gender yang terjadi terhadap lakon Arimbi dan Draupadi diromantisasi oleh penggambaran lakon mereka yang pintar, cantik dan tangguh. Dibalik itu semua, dominasi pria masih terjadi dalam pembentukan dua karakter tersebut. Narasi kuasa dari wayang dan dikonstruksi dalam masyarakat yang selanjutnya menjadi pembahasan utama dalam penelitian ini. Cerminan konstruksi nilai dalam masyarakat diperoleh dari observasi terhadap masyarakat tradisional di Dusun Cengkir Manis, Desa Cinyasag, Kab. Ciamis, Jawa Barat.

\section{Penggambaran Draupadi dan Cerminannya dalam Masyarakat Tradisional Sunda}

Draupadi dalam cerita Mahabharata dianggap sebagai tokoh perempuan yang kuat dan merepresentasikan perempuan modern karena tegas, berani, dan berpegang pada nilai-nilai kebenaran. la dianggap sebagai penggambaran sosok feminis India (Nisha \& Phogat, 2017). Keberanian Draupadi dilihat dari penggambaran karakternya yang tidak egan-segan menyampaikan kritik kepada para suaminya. Draupadi tidak hanya menjadi sosok aktif tetapi juga pasif yang menyimbolkan pembicara dan pendengar yang baik bagi suaminya (Brodbeck \& Black, 2007). Namun, jika ditelisik lebih lanjut yang dimulai dari lahir hingga menikah, Draupadi merupakan repsentasi simbol otoritas laki-laki terhadap perempuan.

Kelahiran Draupadi dikategorikan sebagai gambaran dari dominasi patriarki dimana perempuan digambarkan bukan sebagai entitas mandiri melainkan sebagai entitas yang dibentuk dari hubungannya dengan lelaki (Hidayat, 2004). Berdasarkan cerita Mahabharata ayah Draupadi, Raja Drupada telah dikalahkan oleh Arjuna dan Dorna. Untuk membalas dendam kepada Dorna, Raja Drupada menggelar upacara Putrakameshti untuk mendapatkan anak lelaki. Namun, lahirlah Draupadi dari kobaran api dengan paras yang cantik. Draupadi tidak mempunyai nilai sebagai entitas hidup yang mandiri, melainkan ia akan bernilai lebih jika mampu menjadi senjata untuk membalas dendam 
kepada musuh Raja Drupada. Identitas perempuan yang kerapkali diasosiasikan dengan entitas lain tercermin dalam masyarakat. Berdasarkan hasil observasi pada masyarakat tradisional Sunda, para perempuan yang sudah menikah dan punya anak mempunyai paggilan yang berbeda. Mereka akan dipanggilan dengan sebutan mamah [nama anak pertama]. Sedangkan, perempuan yang tidak juga memiliki anak dari pernikahannya disebut dengan ma gabug. Pelabelan ini menunjukan bahwa entitas perempuan erat kaitannya dengan entitas lainnya, dalam hal ini hubungan tersebut ditandai dengan kehadiran seorang anak. Dengan disematkannya nama ma gabug bagi perempuan yang tak kunjung memiliki keturunan, label bagi perempua kian bertambah. Bahkan di perkotaan pun tak jarang ditemukan panggilan yang berbeda bagi yang sudah menikah. Perempuan tersebut akan dikaitkan dengan nama suam, misalnya Bu Ari. Ari adalah nama dari sang suami.

Dikisahkan Draupadi yang lahir dari api dan kemarahan sang Ayah ini mempunyai paras yang cantik. Kecantikan Draupadi ini diharapkan dapat menjadi senjata untuk mengalahkan lawannya. Lagi-lagi, hal ini merupakan salah satu bentuk dominasi pria terhadap wanita dimana perempuan menjadi komoditas. Komodifikasi merupakan fenomena dimana manusia dianggap sebagai komoditas dari yang tidak bernilai menjadi sesuatu yang bernilai. Sehingga perempuan yang dilekati dengan nilai ekonomis merupakan salah satu bentuk komodifikasi yang dilakukan oleh pria, dalam cerita wayang ini dilakukan oleh ayah Draupadi.

Kecantikan Draupadi akhirnya menarik perhatian raja-raja untuk dapat mempersuntingnya menjadi istri. Raja Drupada menggelar sayembara dengan Draupadi sebagai hadiahnya. Dalam sayembara tersebut, Draupadi bukan memilih suaminya melainkan diserahkan sebagai hadiah kepada Pandawa yang telah memenangkan sayembara. la menjadi hadiah bagi siapapun yang berhasil menyelesaikan segala tantangan yang diberikan sang ayah. Dari cerita ini terlihat bahwa Draupadi tidak memiliki kebebasan dalam memilih pria yang ia sukai. Penyerahan Draupadi sebagai hadiah kepada Pandawa pun kembali meneguhkan komodifikasi perempuan yang terjadi dalam cerita wayang Mahabharata. Ini mematahkan anggapan bahwa Draupadi dianggap sebagai contoh bagi perempuan untuk dapat memilih pasangannya yang pantas untuk dinikahi (Nisa \& Phogat, 2018)

Selain itu, Draupadi pun lebih dikenal sebagai simbol prostitusi karena harus melayani lima suami yang ditentukan melalui sayembara (Spivak dalam Kaur, 2018). Draupadi yang diceritakan mempunyai wajah yang cantik ini digambarkan sebagai perempuan yang kuat yang setia kepada lima suaminya. Namun, ketika karakter ini diteliti lebih lanjut, Draupadi telah menjadi korban represi dan supresi (Gupta dalam Kaur, 2018). 
Draupadi yang akhirnya bersuamikan lima orang Pandawa ini lagi lagi bukan sebagai representasi perempuan modern dengan haknya memilih lebih dari satu suami melainkan sebagai bentuk dari kemenangan pria. Draupadi menjadi hadiah atas kemenangan para Pandawa. Menurut Kaur (2018), Kunti yang mempunyai kekuatan suparanutural telah mengetahui bahwa yang dibawa pulang oleh anak-anaknya bukan sebuah barang melainkan seorang penempuan, namun Kunti tetap meminta mereka untuk membaginya dengan adil kepada kelima anaknya tersebut. Draupadi akhirnya diobjektifikasi dengan harus dibagikan secara adil kepada kelima suaminya.

Namun dalam wayang Sunda, cerita tersebut mengalami sedikit perubahan. Draupadi memang dimenangkan oleh kelima Pandawa tetapi dalam keseluruhan cerita Draupadi hanya disebut sebagai istri dari Yudistira, kakak tertua dalam keluarga Pandawa. Hal ini dilakukan karena perempuan tidak boleh bersuamikan lebih dari satu pria dalam agama Islam. Namun, status Draupadi sebagai hadiah sayembara bagi Pandawa tetap diceritakan dalam pewayangan Sunda yang mana merupakan simbol komodifikasi dan objektifikasi terhadap perempuan. Pandawa dianggap perkasa dan adiguna karena mampu mengalahkan semua lawan dalam sayembara tersebut, sedangkan Draupadi dijadikan sebagai hadiah dari keperkasaan Pandawa.
Praktek objektifikasi pun terdapat pada adegan dimana Pandawa kalah berjudi dengan Kurawa. Draupadi dijadikan taruhan judi. Nampak jelas bahwa Draupadi dianggap sebagai objek dimana suami mempuyai otoritas terhadap tubuh perempuan. Otoritas atas tubuh selalu berhubungan dengan kekuasaan. Ketidakmampuan perempuan dalam menentukan kuasa atas tubuhnya sendiri membuat perempuan menjadi objek komodifikasi pihak lain. Seperti yang terlihat dalam adegan dimana Draupadi dipertaruhkan di meja judi. Draupadi yang digambarkan sebagai wanita yang cerdas dan tegas tetap saja tidak dapat mengalahkan dominasi pria terhadap dirinya sebagai seorang istri. Ketika diminta untuk melepaskan sarinya sebagai imbalan atas kemenangan Kurawa di meja judi, Draupadi tidak dapat menolak. Adegan ini membalut komodifikasi perempuan ke dalam narasi kepatuhan dan kesetiaan terhadap suami. Romantisasi ini menyembunyikan ketidakberdayaan perempuan atas otoritas tubuhnya sendiri. Kesetiaan Draupadi kepada suami yang seperti ini diterapkan sebagai nilai ideal seorang istri dalam masyarakat tradisional Sunda. Perempuan dalam masyarakat Sunda harus mengikuti perintah dan keinginan suami.

Praktek dominasi dan objektifikasi dalam wayang yang sudah mengakar dalam kebudayaan Sunda diturunkan kembali dalam bentuk peribahasa dan babasan. Sehingga tidak jarang munculnya tokoh wayang ketika yang lebih tua memberi nasihat kepada yang 
lebih muda. Dalam peribahasa Sunda, perempuan digambarkan dengan kasur, dapur, dandan (Zulaikha \& Purwaningsih, 2019). Nilai ini menjunjung tinggi konsep bahwa perempuan harus dapat menyenangkan suami dengan berdandan yang cantik, memasak dan memuaskan suami di ranjang. Perempuan tidak diberikan kesempatan untuk dapat dapat lepas dari otoritas pria terhadap tubuhnya. Bahkan tubuh perempuan pun diatur sedemikian rupa ke dalam konsep ideal perempuan Sunda. Perempuan yang ideal dan layak dijadikan istri adalah perempuan yang mempunyai tubuh yang proporsional, enak dilihat mata, berkaki layaknya batang pisang, dan berkulit putih. Oleh karena itu, tubuh dapat dikatakan sebagai bentuk eksistensi manusia. Tubuh perempuan yang dilekati dengan identitas sosial ini akan mempuyai daya jual tinggi dalam masyarakat jika mampu menampilkan citra cantik, dan muda (Prabasmoro, 2006). Nilai jual tinggi ini dapat menempatkan perempuan pada kelas sosial tertinggi sebagai konsep ideal perempuan bagi para pria. Seperti halnya kecantikan Draupadi yang menjadi alasan para raja ingin mempersuntingnya. Tubuh merupakan representasi dan sketsa diri terhadap dunia sosial (Barker, 2005). Sehingga tubuh menjadi hal penting dalam menentukan hubungan seseorang dengan orang lainnya yang menjadi identitas personal dan sosial (Raditya, 2014). Oleh karena itu baik dalam cerita wayang, peribahasa maupun babasan Sunda konsep tubuh menjadi sorotan. Bagaimana identitas tubuh diproduksi dan dikonsumsi menjadi konsep penting dalam memahami relasi kuasa yang terjadi dalam masyarakat. Pembentukan identitas tubuh ini akhirnya melahirkan konstruksi perempuan yang selalu dikaitkan dengan laki-laki. Perempuan dianggap mempunyai nilai tukar tinggi jika sudah terbukti dinikahi oleh pria dan mempunyai anak. Baik dalam cerita Mahabharata mapun peribahasa Sunda, perempuan yang cantik tetap menjadi tokoh utama. Sedangkan bagi perempuan yang belum menikah, julukan perawan tua akan terus melekat. Julukan perawan tua mempunyai makna negatif yang disematkan kepada perempuan yang tak kunjung menikah. Sedangkan jika lelaki menunda untuk menikah akan dianggap biasa. Ketimpangan status sosial ini merupakan salah satu bentuk dari otoritas laki-laki terhadap tubuh perempuan. Bahkan hingga menikah perempuan tetap mendapat julukan jika tak kunjung memiliki keturunan dengan sebutan ma gabug. Namun, perempuan memiliki banyak keturunan tidak lantas lepas dari label dalam masyarakat. Perempuan yang memiliki banyak anak layaknya Kurawa mendapatkan sebutan henceut ucingeun yang berarti perempuan tersebut disimbolkan dengan kucing yang mampu melahirkan banyak anak. Henceut ini sendiri dalam Bahasa Indonesia artinya alat reproduksi. Sedangkan ucingeun berarti mempunyai sifat seperti kucing. Tetapi para suami tidak mendapatkan julukan yang serupa. Julukan ini hanya disematkan kepara para istri saja. Ini 
menunjukkan bahwa otoritas terhadap tubuh perempuan tidak dimiliki secara mandiri melainkan dihubungkan dengan entitas yang lain. Fenomena ini dapat dilihat sebagai ketimpangan terhadap perempuan. Jika dilihat secara keseluruhan, label terhadap perempuan lebih banyak daripada label terhadap laki-laki dalam kebudayaan Sunda. Ini membuat perempuan menjadi bagian yang ditandai dalam masyarakat. Konsep ditandai dan tidak ditandai ini merupakan istilah dalam linguistik untuk menggambarkan satu bagian yang digarisbawahi, sedangkan yang lain tidak (Trubetzkoy dalam Brekhus, 1996). Inilah yang terjadi pada label yang melekat pada perempuan dalam budaya Sunda. Perempuan ditandai dengan konsep sosial yang dinamakan sebagai social marking (Brekhus, 1996). Karakteristik dari marked dan unmarked society menunjukkan dominasi dari unmarked society. Brekhus (1996) menyebutkan bahwa karakteristik dari marked society berlaku hanya untuk mereka yang ditandai, sedangkan atribut yang melekat pada unmarked society berlaku universal bagi semua manusia. Marked society dalam pembahasan ini adalah perempuan sedangkan unmarked society adalah laki-laki. Dalam budaya Sunda perempuan ditandai dengan atribut seksualitas dan tingkah laku yang akkhirnya mengarah pada objektifikasi dan komodifikasi terhadap perempuan. Konstruksi marked dan unmarked inilah yang akhirnya membentuk identitas sosial perempuan dalam budaya Sunda.

\section{Penggambaran Arimbi dan Cerminannya dalam Masyarakat Tradisional Sunda}

Arimbi digambarkan sebagai putri raksasa yang jatuh cinta kepada Bhima. Arimbi bertemu dengan bima ketika keluarga Pandawa tersebut sedang menuju hutan untuk mendirikan tempat tinggal. Rupanya hutan tersebut adalah milik raksasa pemakan manusia yang memang sedang menantikan kedatangan manusia. Raja raksasa, kakak lelaki dari Arimbi ingin menjadikan pandawa sebagai santapannya. Namun, Arimbi jatuh cinta kepada keperkasaan Bhima. Dalam cerita tersebut, Arimbi merayu Bhima dengan segala cara, tetapi tidak berhasil. Bhima menolaknya karena berwajah jelek layaknya raksasa.

"Bagaimana Bhima, maukah kau menikah denganku?"

"Najis"

Penggalan dialog yang telah diterjemahkan ke dalam Bahasa Indonesia di atas terdapat dalam cerita wayang Sunda berjudul "Arimbi Rarabi”. Percapakan tersebut menunjukkan bahwa perempuan akan lebih bernilai di mata lelaki jika mempunyai paras yang menawan. Bahkan cepot memperkuat dengan memberikan pujian kepada Arimbi karena badan Arimbi yang montok. Namun, Cepot pun tidak menyukai Arimbi karena ia tampak seperti raksasa yang buruk rupa.

"Duh badannya bagus, montok, tapi sayang ..."

Jurnal IImu Sosial dan Humaniora | 44 
Disini terlihat begitu besar pengaruh paras seorang wanita terhadap diterima atau tidaknya dalam masyarakat. Dalam masyarakat Sunda wanita jelek dan hitam dikenal dengan sebutan "tunggul karuhu" mukanya seperti kayu bakar. Kayu bakar ini menyimbolkan perempuan yang jelek, tidak terawat dengan kulit hitam legam. Tampak jelas sekali bahwa perempuan lebih cenderung dilihat sebagai objek pemuas bagi para lelaki dengan kriteria tertentu, misalnya cantik, putih dan mulus. Le (2014) menyebut fenomena ini dengan instilah male gaze. Male gaze adalah suatu konsep dimana seorang pria heteroseksual menempatkan perempuan sebagai objek dan menghakimi mereka hanya berdasarkan penampilan fisiknya. Perempuan menajadi kelompok marginal dimana selalu didominasi oleh kelas yang berkuasa yakni pria. Objektifikasi ini terus berlangsung sepanjang cerita dimana akhirnya Bhima menerima Arimbi karena Arimbi berubah menjadi wanita yang cantik jelita.

Pengakuan cinta Arimbi kepada Bhima yang berakhir pada penolakan ini menunjukkan hal lainnya yakni perempuan tidak memilih pria melainkan sebaliknya. Ini memperlihatkan terjadinya relasi kuasa antara pria dan wanita dimana prialah yang memegang peranan penting dalam memutuskan sesuatu. Relasi kuasa ini dapat kita jumpai dalam kehidupan sehari-hari dimana lelaki akan mengatakan "menikahi perempuan" sedangkan perempuan akan mengatakan "dinikahi". Terlihat bahwa nilai - nilai yang dianut dalam masyarakat tercermin ke dalam bahasa yang digunakan. Berdasarkan observasi yang telah dilakukan terhadap masyarakat tradisional Sunda, perempuan cenderung menunggu lamaran dari pria. Jika ada pria yang melamar, pihak perempuan sangat disarankan untuk menerima kalau tidak menerima mereka akan terkena pamali. Pamali ini adalah sesuatu yang tabu yang harus dihindari jika tidak ingin mendapatkan sesuatu yang tidak diinginkan. Dengan adanya kebudayaan yang seperti ini perempuan dalam budaya Sunda dibatasi dalam membuat keputusan dan menentukan pilihan. Setelah menikah pun perempuan dalam Budaya Sunda harus menerima apapun dari suami. Perempuan Sunda yang telah menikah diibaratkan sebagai dulang. Dulang adalah perkakas dapur yang digunakan untuk menyimpan nasi yang baru saja matang. Bentuk dulang mirip sekali dengan lesung yang mempunyai mulut wadah yang lebar dan mengecil ke bawah layaknya corong. Dulang yang mengumpakan perempuan ini dianggap mempunyai nilai yang sama dengan konsep menerima sesuatu. Masih dipegang teguhnya nilai-nilai dalam wayang dan kearifan lokal lainnya oleh masyarakat tradisional Sunda mengisyaratkan bahwa relasi kuasa yang timpang masih akan terus berlanjut.

Selanjutnya, dalam cerita ini Arimbi digambarkan pula Arimbi sebagai seorang penggoda. Tidak jauh berbeda dengan cerita Draupadi yang 
dianggap sebagai pelacur karena dinikahi oleh lima suami sekaligus sehingga tidak ditunjukkan secara gamblang dalam cerita Mahabharat versi Sunda. Arimbi pun mendapatkan label negatif karena dianggap terlalu agresif mengejar cinta Bhima Hal ini didasari oleh konstruksi budaya menggambarkan perempuan sebagai makhluk yang lembut, tunduk, dan penyayang (Fakih, 2008). Sifat inilah yang terkonstruksi secara sosial dalam jangka waktu dalam sebuah masyarakat. Fenomena ini disebut oleh common culture oleh William (dalam Eagleton, 2000). Common culture merupakan nilai yang dibentuk dan dijalankan bersama oleh sekelompok orang. Konstruksi sosial yang dibentuk terhadap perempuan merupakan produk dari pemikiran kolektif terhadap entitas perempuan. Konstruksi sosial ini juga merekonstruksi bahasa yang digunakan, seperti yang Kramsch (1998) sebutkan bahwa bahasa dan budaya saling berkaitan karena bahasa yang diproduksi oleh sekelompok orang merupakan hasil dari pengalaman yang sama. Perempuan dalam budaya Sunda pun mempunyai nilai-nilai tersebut. Perempuan Sunda tidak sepantasnya mengejar lelaki layaknya Arimbi. Nilai ini tertuang dalam peribahasa Sunda yang mengumpakan perempuan dengan postur tubuh kucing yang badannya condong ke belakang. Tubuh kucing yang seperti ini menyimbolkan perempuan yang gemar berhias untuk mendapatkan seorang pria. Perempuan dalam budaya Sunda pun tidak disarankan seperti Arimbi yang langsung menunjukkan ketertarikan pada lawan jenis. Perempuan harus bertingkah laku layaknya merpati, lindeuk japati. Perempuan dalam budaya Sunda harus tampak seperti mudah ditaklukkan tapi kenyataannya sulit didapatkan. Perempuan yang disimbolkan dengan burung tangkapan ini lagi-lagi menunjukkan adanya obektifikasi. Perempuan disamakan dengan sebuah hewan tangkapan.

Cerita Arimbi ini juga menggambarkan bahwa kebaikan hati seorang perempuan menempati posisi kedua setelah kecantikan. Perempuan memang cenderung dikaitkan dengan keindahan, dan kecantikan. Sedangkan, tingkah laku agresif lebih cenderung disematkan bagi laki-laki (Tilker, 1975). Begitu pula yang terjadi dalam masyarakat tradisional Sunda. Budaya Sunda memilki banyak sekali peribahasa yang memberikan gambaran kecantikan ideal seorang perempuan. Penggambaran perempuan yang cantik sangat spesifik dalam bahasa Sunda. Perempuan yang cantik menurut peribahasa Sunda adalah perempuan yang mempunyai bentuk badan yang proporsional atau "semok", berkaki jenjang, memiliki rambut yang terurai, berkulit putih dan memiliki kuku yang indah. Berdasarkan hasil observasi, nilai seperti inilah yang memang dikonsepkan untuk sosok ideal seorang perempuan layaknya kecantikan dewi Sinta.

Kecantikan dan feminitas perempuan merupakan dua hal yang tidak dapat dipisahkan dari budaya patriarki. Karena tuntunan inllah, 
perempuan pun cenderung mencari pengakuan laki-laki terhadap kecantikan dan feminitasnya (Prabasmoro, 2006). Ini terlihat dari adegan dimana Arimbi berubah menjadi wanita yang cantik jelita agar dapat diterima oleh Bhima. Ini pun terjadi dalam masyarakat Sunda. Perempuan harus dapat berhias diri dengan batasan-batasan tertentu. Perempuan harus memakai bedak yang tidak terlalu tebal agar tidak seperti dodol bulukan atau careuh bulan. Dodol bulukan merupakan perumpamaan bagi perempuan yang dibedak tidak rata layaknya dodol yang berjamur. Sedangkan careuh bulan ditujukan bagi perempuan yang bedaknya terlalu tebal, putih seperti bulan di langit yang gelap pada malam hari. Perempuan pun tidak selayaknya berlipstik terlalu merah. Selain wajah, perempuan cantik dalam budaya Sunda diberikan kepada perempuan yang memiliki betis seperti pohon pisang yang jenjang.

Konsep ideal dari seorang perempuan Sunda yang cantik jelita ini menggambarkan bagaimana konsep tubuh wanita dikonstruksi secara sosial. Kecantikan adalah simbol dari tubuh wanita dimana awalnya merupakan tubuh alami (natural body) kemudian menjadi tubuh sosial (Abdullah, 2006). Tubuh sosial adalah konsep dimana tubuh seseorang dilabeli dengan konstruksi sosial dalam masyarakat. Sehingga bukan lagi kepemilikan pribadi seseorang melainkan sudah terasosiasi dengan nilai bersama.

\section{SIMPULAN DAN SARAN}

Sebagai sebuah ideologi, patriarki dapat dimanifestasikan melalui perempuan dan tubuhnya yang berujung pada ketimpangan relasi yang terjadi antara perempuan dan laki-laki. Ketimpangan ini semakin kental terlihat dengan munculnya opresi dan supresi terhadap perempuan. Dalam ideologi patriarkat ini identitas perempuan tidak digambarkan secara terpisah melainkan merupakan pemaknaan dari hubungannya dengan laki-laki. Sehingga jelas dalam prakteknya bahwa perempuan tidak dapat memaknai dirinya sendiri secara terpisah.

Relasi kuasa daalam cerita Mahabharata begitu jelas terlihat melalui penggambaran tokoh-tokoh perempuan yang dalam penelitian ini difouskan pada Draupadi dan Arimbi. Kedua tokoh dapat dikatakan sebagai korban dari kuasa lelaki terhadap perempuan. Ini ditunjukan melalui adanya praktek komodifikasi dan objektifikasi yang dirasakan oleh tokoh Draupadi dan Arimbi. Draupadi diberikan sebagai hadiah kepada para Pandawa yang akhirnya harus dibagi secara merata dan adil atas perintah dari Dewi Kunti, lbu dari Para Pandawa. Draupadi dinilai selayaknya sebuah barang. Dalam cerita Mahabharata Draupadi menjadi komoditas dari sang ayah dengan mempunyai nilai jual atau tukar yang tinggi karena cantik dan pintar. Situasi Arimbi pun tidak jauh berbeda. Arimbi harus beurubah menjadi wanita yang cantik agar dapat dipersunting oleh Bhima. Keadaan ini menjukkan 
bagaimana Arimbi tidak mempunyai otoritas terhadap tubuh dirinya sendiri. Identitas tubuh ini menjadi identitas sosial dimana ditentukan oleh pihak yang berkuasa. Dalam konteks ini, pihak yang berkuasa adalah lelaki di mana mereka menentukan konsep ideal seorang perempuan yang diterima sebagai nilai ideal bagi masyarakat Sunda. Perempuan merupakan marked society. Sedangkan laki-laki adalah unmarked society. Unmarked society mempunyai keistimewaan yakni dapat menentukan nilai mana yang akan diterapkan dalam masyarakat bagi kelompok marginal atau perempuan.

Pengakuan cinta Arimbi yang ditolak oleh Bhima pun menunjukkan relasi kuasa antara perempuan dan laki-laki. Perempuan tidak ditempatkan sebagai pihak yang berwenang untuk memilih melainkan pihak yang dipilih. Narasi gender yang dibentuk dalam cerita wayang Sunda ini merupakan cerminan dari sistem sosial dalam masyarakat Sunda. Ideologi patriarki yang membangun sistem sosial dalam masyarakat tercermin pula dalam produk budaya lainnya seperti peribahasa dan babasan. Nilai yang terus dipertahankan ini kemudian kembali mendekonstruksi budaya sehingga terus menerus menghasilkan produk yang sama. Jika nilai ini terus dipertahankan maka ketimpangan gender yang terjadi dalam masyarakat pun dapat semakin melebar.

\section{UCAPAN TERIMAKASIH}

Peneliti mengucapkan terima kasih kepada Universitas Perjuangan Tasikmalaya atas bantuan dana yang telah diberikan pada tahun akademik 2019/2020.

\section{DAFTAR PUSTAKA}

Abdullah, I. (2006). Konstruksi dan Resproduksi Kebudayaan. Yogyakarta: Pustaka Belajar.

Barker, C. (2005). Cultural Studies. Yogyakarta: Bentang.

Brodbeck, S. \& Brian B, (eds.). (2007). Gender and Narrative in the Mahabharata. London: Routledge.

Brekhus, W. (1996). Social Marking and the Mental Coloring of Identity: Sexual Identity Construction and Maintanace in the United States. Sociological Forum, 11(3), 497522.

Eriyanto. (2001). Analisis Wacana: Pengantar Analisis Teks Media. Yogyakarta: LKIS.

Eagleton, T. (2000). The Idea of Culture. Oxfors: Blackwell Publishers Inc

Fakih, M. (2008). Analisis Gender dan Tansformasi Sosial. Yogyakarta: Pustaka Pelajar.

Geertz, C. (1973). Interpretation of Cultures. New York: Basic Books

Guritno, P. (1988). Wayang, kebudayaan Indonesia dan pancasila. Jakarta: Indonesia University Press.

Hasuna, K. (2015). Analisis Nilai Filosofis dalam Wayang Banjar. LENTERA Jurnal IImiah Kependidikan, 10(1), 44-58.

Hidayat, R. (2004). IImu yang Seksis. Yogyakarta: Jendela.

Jurnal IImu Sosial dan Humaniora | 48 
Kaur, H. (2018). Draupadi: A Victim of Gender Opression. Pramana Research Journal, 8(9), 298-304.

Koentjaraningat. (2002). Bunga Rampai Kebudayaan, Mentalitas, dan Pembangunan. Jakarta: PT Gramedia Pustaka.

Kramsch, C. (1998). Language and Culture. New York: Oxford University Press.

Lazar, M. M. (2005). Feminist Critical Discourse Analysis. New York: Macmillan.

Le, C. N. (2017). The Homogenization of Asian Beauty. Diunduh dari https://thesocietypages.org/paper s/homogenization-of-asianbeauty.

Miranti \& Amzy. (2018). Analisis Karakter Tokoh Wayang Srikandi dalam Lakon Perang Bahratayuda sebagai Pembelajaran Karakter Utama Remaja. Jurnal Kreasi Seni dan Budaya, 1(1), 20-24.

Nisha \& Phogat G. (2017). Women of Substance and Heroism: A Study from "The Mahabharata". Research Journal of English Language and Literature (RJELAL), 5(1), 256-260.

Prabasmoro, A.P. (2006). Kajian Budaya Feminis: Tubuh, Sastra dan Budaya Pop. Jakarta: Jalasutra.

Raditya, A. (2014). Sosiologi Tubuh. Yogyakarta: Kaukaba Dipantara.

Sabunga. (2016). Nilai - Nilai Karakter dalam Pertunjukan Wayang Golek Purwa. Jurnal Sosioreligi, 14(1), 1-13.
Schauf. (2018). Searching for Hidden Bridges in Co-occurrence Networks from Javanese Wayang Kulit. Journal of Historical Network Research, 2, 26-52.

Setyowati, H. (2013). Representasi Srikandi dalam Pertunjukan Wayang Lakon Bisma Gugur. Journal of Arts Education CATHARSIS, 2(1), 28-33.

Sharma A. K. (2013). Perempuanperempuan Mahabarata. Gramedia: Jakarta.

Sudjarwo, H. S. (2010). Rupa dan Karakter Wayang Purwa. Jakarta: Kaki Langit Kencana.

Sukmawan \& Supendi. (2016). Structural Presupposition in Wayang Golek. Journal of Applied Linguistics and Language Research, 3(7), 123-131.

Suryana, J. (2002). Wayang Golek Sunda:kajian Estetika Rupa Tokoh Golek. Bandung: PT. Kiblat Utama.

Tilker, H.A. (1975). Development Psychology Today. New York: Random House, Onc.

Tofani, M.A. (2013). Mengenal Wayang Kulit Purwa Wujud, Karakter dan Kisahnya. Surabaya: Pustaka Agung Harapan.

Zulaikha, F. \& Purwaningsih, P. (2019). Representasi Identitas Perempuan dalam Ranah Domestik- Sebuah Kajian Semiotika Budaya pada Peribahasa Sunda. Nusa: Jurnal Ilmu Bahasa dan Sastra, 14(3), 341-352.

Jurnal IImu Sosial dan Humaniora | 49 